\title{
Change in $\mathrm{HbA}_{1 \mathrm{c}}$ Across the Baseline $\mathrm{HbA}_{1 \mathrm{c}}$ Range in Type 2 Diabetes Patients Receiving Once-Weekly Dulaglutide Versus Other Incretin Agents
}

\author{
Raffaella Gentilella • Irene Romera - Claudia Nicolay • \\ Raffaella Buzzetti · Luis Alberto Vázquez · Giorgio Sesti
}

Received: January 9, 2019 / Published online: May 4, 2019

(C) The Author(s) 2019

\begin{abstract}
Introduction: This exploratory post hoc analysis investigated the relative changes in glycated haemoglobin $\left(\mathrm{HbA}_{1 \mathrm{c}}\right)$ in patients with type 2 diabetes mellitus (T2DM) treated with dulaglutide versus active comparators across a continuous range of baseline $\mathrm{HbA}_{1 \mathrm{c}}$ values using data from three phase III randomised controlled trials.
\end{abstract}

Enhanced Digital Features To view enhanced digital features for this article go to https://doi.org/10.6084/ m9.figshare.7998908.

Electronic Supplementary Material The online version of this article (https://doi.org/10.1007/s13300019-0625-3) contains supplementary material, which is available to authorized users.

R. Gentilella

Eli Lilly Italia, Sesto Fiorentino, Florence, Italy

I. Romera $(\bowtie)$

Eli Lilly and Company, Alcobendas, Madrid, Spain e-mail: romera_irene@lilly.com

C. Nicolay

Lilly Deutschland GmbH, Bad Homburg, Germany

R. Buzzetti

Department of Experimental Medicine "Sapienza", University of Rome, Rome, Italy

L. A. Vázquez

Hospital Marqués de Valdecilla, Santander, Spain

G. Sesti

University Magna Graecia, Catanzaro, Italy
Methods: Data from patients receiving onceweekly dulaglutide 0.75 and $1.5 \mathrm{mg}$, once-daily sitagliptin $100 \mathrm{mg}$, once-daily liraglutide $1.8 \mathrm{mg}$ or twice-daily exenatide $10 \mu \mathrm{g}$ in the intent-totreat populations in the AWARD-5, AWARD-6 and AWARD-1 trials were analysed using last observation carried forward analysis of covariance. Starting with the predefined statistical model from each study, the type of association between $\mathrm{HbA}_{1 \mathrm{c}}$ baseline and change at 26 weeks was modelled. Consistency of treatment effect was assessed via treatment-by-baseline $\mathrm{HbA}_{1 \mathrm{c}}$ interaction terms.

Results: Improvements in $\mathrm{HbA}_{1 \mathrm{c}}$ occurred in all treatment groups across the entire baseline $\mathrm{HbA}_{1 \mathrm{c}}$ range. The relationship between $\mathrm{HbA}_{1 \mathrm{c}}$ baseline and magnitude of change was linear in all treatment groups, with greater reductions in patients with higher baseline $\mathrm{HbA}_{1 \mathrm{c}}$ values. Across the continuum of baseline $\mathrm{HbA}_{1 \mathrm{c}}$ values, patients treated with dulaglutide $1.5 \mathrm{mg}$ achieved a similar mean $\mathrm{HbA}_{1 \mathrm{c}}$ reduction to patients receiving liraglutide $1.8 \mathrm{mg}$ and a greater reduction than patients receiving twicedaily exenatide or sitagliptin. In AWARD-5, the treatment-by-baseline $\mathrm{HbA}_{1 \mathrm{c}}$ interaction $P$ value (0.001) demonstrated progressively greater $\mathrm{HbA}_{1 \mathrm{c}}$ reduction in dulaglutide-treated compared with sitagliptin-treated patients as baseline $\mathrm{HbA}_{1 \mathrm{c}}$ increased.

Conclusion: Our results suggest that dulaglutide is an appropriate therapeutic option for patients with T2DM across a wide range of 
baseline $\mathrm{HbA}_{1 \mathrm{c}}$ values, including those with poor metabolic control.

Funding: Eli Lilly and Company.

Plain Language Summary: Plain language summary available for this article.

Keywords: Dulaglutide; $\mathrm{HbA}_{1 \mathrm{c}}$; Incretin-based therapy; Range metabolic control; Type 2 diabetes mellitus

$\begin{array}{ll}\text { Abbreviations } \\ \text { ANCOVA } & \text { Analysis of covariance } \\ \text { BID } & \text { Twice daily } \\ \text { BMI } & \text { Body mass index } \\ \text { CI } & \text { Confidence interval } \\ \text { DPP-4 } & \text { Dipeptidyl peptidase-4 } \\ \text { DU } & \text { Dulaglutide } \\ \text { EXE } & \text { Exenatide twice daily } \\ \text { GLP-1 RA } & \text { Glucagon-like peptide-1 receptor } \\ & \text { agonists } \\ \text { HbA } 1 \text { 1c } & \text { Glycated haemoglobin } \\ \text { ITT } & \text { Intent-to-treat } \\ \text { LIRA } & \text { Liraglutide } \\ \text { LOCF } & \text { Last observation carried forward } \\ \text { SD } & \text { Standard deviation } \\ \text { SITA } & \text { Sitagliptin } \\ \text { T2DM } & \text { Type 2 diabetes mellitus }\end{array}$

\section{PLAIN LANGUAGE SUMMARY}

The high blood glucose levels that characterise type 2 diabetes mellitus (T2DM) are treated using antihyperglycaemic drugs. Patients' responses to antihyperglycaemic drugs, which are usually evaluated by measuring glycated haemoglobin $\left(\mathrm{HbA}_{1 \mathrm{c}}\right)$, are affected by several factors, including the patient's baseline $\mathrm{HbA}_{1 \mathrm{c}}$ level. Previous investigations of this topic have involved dividing the baseline $\mathrm{HbA}_{1 \mathrm{c}}$ values of the patient population into a number of categories. However, this loses potentially valuable information. In this analysis, we treated baseline $\mathrm{HbA}_{1 \mathrm{c}}$ as a continuous variable. Our analysis used data from three large clinical trials to investigate changes in $\mathrm{HbA}_{1 \mathrm{c}}$ in patients with T2DM who received one of four different antihyperglycaemic agents: dulaglutide (0.75 or 1.5 mg once weekly), sitagliptin (100 mg once daily), liraglutide (1.8 mg once daily), or exenatide (10 $\mu \mathrm{g}$ twice daily). The patients had a range of baseline $\mathrm{HbA}_{1 \mathrm{c}}$ values.

In all treatment groups, improvements in $\mathrm{HbA}_{1 \mathrm{c}}$ occurred across the entire baseline $\mathrm{HbA}_{1 \mathrm{c}}$ range and patients with higher baseline $\mathrm{HbA}_{1 \mathrm{c}}$ values showed greater reductions. The mean $\mathrm{HbA}_{1 \mathrm{c}}$ reduction was similar in patients treated with dulaglutide $1.5 \mathrm{mg}$ and those receiving liraglutide $1.8 \mathrm{mg}$ across the range of baseline $\mathrm{HbA}_{1 \mathrm{c}}$ values. However, patients receiving dulaglutide $1.5 \mathrm{mg}$ had greater reductions than patients receiving exenatide or sitagliptin. As baseline $\mathrm{HbA}_{1 \mathrm{c}}$ increased, patients receiving dulaglutide had progressively greater $\mathrm{HbA}_{1 \mathrm{c}}$ reductions compared with those receiving sitagliptin. These results suggest that dulaglutide is an appropriate therapy for patients with T2DM across a wide range of baseline $\mathrm{HbA}_{1 \mathrm{c}}$ values, including those with poor blood glucose control.

\section{INTRODUCTION}

For patients with type 2 diabetes mellitus (T2DM), treatment with most antihyperglycaemic agents-including incretin-based therapies, such as glucagon-like peptide-1 receptor agonists (GLP-1 RA) and dipeptidyl peptidase- 4 (DPP-4) inhibitors-is associated with an improvement in glycated haemoglobin $\left(\mathrm{HbA}_{1 \mathrm{c}}\right)$ levels [1-4]. Baseline $\mathrm{HbA}_{1 \mathrm{c}}$ is a predictor of $\mathrm{HbA}_{1 \mathrm{c}}$ change in patients responding to treatment, with greater reductions in $\mathrm{HbA}_{1 \mathrm{c}}$ levels occurring in patients with higher baseline values [5-11]. Of clinical interest is a meta-analysis involving DPP-4 inhibitors, which indicated that the baseline $\mathrm{HbA}_{1 \mathrm{c}}$ level was the strongest predictive factor for change in $\mathrm{HbA}_{1 \mathrm{c}}$ [8]. Similar results have been found for the GLP-1 RA dulaglutide [11].

Dulaglutide has demonstrated significant improvements in $\mathrm{HbA}_{1 \mathrm{c}}$, and fasting and postprandial blood glucose levels in patients with T2DM, and is associated with a substantial percentage of patients achieving $\mathrm{HbA}_{1 \mathrm{c}}<7 \%$ $(53.0 \mathrm{mmol} / \mathrm{mol})$ [12-19]. These effects are durable up to 104 weeks $[16,20]$. This agent also demonstrates a potential for weight loss and has 
a safety profile similar to that of other agents in the GLP-1 RA class [21].

A post hoc analysis of data from the AWARD trials that used gradient-boosting analysis and multivariable regression to examine baseline factors associated with glycaemic response in dulaglutide-treated patients with T2DM [11] found that higher baseline $\mathrm{HbA}_{1 \mathrm{c}}$ was the major factor associated with a greater reduction in $\mathrm{HbA}_{1 \mathrm{c}}$ (a $1 \%$ [11 mmol/mol] increase in baseline $\mathrm{HbA}_{1 \mathrm{c}}$ was associated with a decrease in $\mathrm{HbA}_{1 \mathrm{c}}$ of $0.60 \%$ [6.54 mmol $/ \mathrm{mol} ; P<0.0001]$ ).

When comparing antihyperglycaemic agents with each other, it is often of interest to understand whether patients experience different responses to each treatment according to baseline or disease characteristics of interest. In the case of a continuous variable, such as baseline $\mathrm{HbA}_{1 \mathrm{c}}$, this is typically done by dividing the population into subgroups on the basis of $\mathrm{HbA}_{1 \mathrm{c}}$ level before applying the statistical model [22-25]. For example, both Bain et al. [24] and Gallwitz et al. [25] divided their respective GLP-1 RA-treated populations into two subgroups (baseline $\mathrm{HbA}_{1 \mathrm{c}}<8.5 \%$ and $\geq 8.5 \%$ ). Baseline $\mathrm{HbA}_{1 \mathrm{c}}$ was thus treated as a categorical variable. Although informative, this type of analysis fails to utilise all the information provided by a continuous variable [26]. It is also associated with reduced statistical power, increased risk of a false positive result, underestimation of the extent to which the outcome varies among groups, and potential concealment of a non-linear relationship between variable and outcome [26]. In addition, this approach can result in the performance of multiple analyses if more than one set of cutoffs is used to generate the categories (e.g. $<8.5 \%$ vs $\geq 8.5 \%$ followed by $<7.5 \%$ vs $\geq 7.5 \%$ ) and, as a consequence, it may generate conflicting results. In order to avoid these problems, in the current analysis we have treated baseline $\mathrm{HbA}_{1 \mathrm{c}}$ as a continuous variable-an approach that allows us to fully explore the relationship between baseline $\mathrm{HbA}_{1 \mathrm{c}}$ and antihyperglycaemic endpoints both within and between treatment groups. This analysis-which represents an alternative to the more typical (categorical) analysis-should provide a deeper understanding of changes in antihyperglycaemic measures associated with individual agents in patients with different baseline $\mathrm{HbA}_{1 \mathrm{c}}$ values, and of the relative changes associated with different agents in patients at each level of baseline glycaemia. To our knowledge, this type of analysis has not been previously performed on $\mathrm{HbA}_{1 \mathrm{c}}$ data from patients with T2DM who are receiving incretin therapies.

In the present post hoc analysis, we used data from three phase III randomised controlled AWARD trials to investigate the consistency of glycaemic response across a continuous range of baseline $\mathrm{HbA}_{1 \mathrm{c}}$ values, in patients treated with once-weekly dulaglutide $1.5 \mathrm{mg}$ and $0.75 \mathrm{mg}$ versus other incretin-based therapies: the DPP-4 inhibitor, once-daily sitagliptin $100 \mathrm{mg}$ (AWARD-5 [13]), and the GLP-1 RAs, once daily liraglutide $1.8 \mathrm{mg}$ (AWARD-6 [14]) and twicedaily exenatide $10 \mu \mathrm{g}$ (AWARD-1 [15]). These three AWARD trials were selected for this analysis because they involved an incretin-based comparator and enrolled patients with T2DM with a wide and continuous range of baseline $\mathrm{HbA}_{1 \mathrm{c}}$ values. Each of these trials demonstrated that dulaglutide is at least as efficacious as these other incretin-based therapies and has an acceptable tolerability and safety profile.

\section{METHODS}

This exploratory post hoc analysis included data from all adult patients enrolled in the intent-totreat (ITT) populations who received active treatment (dulaglutide or another incretinbased therapy) in AWARD-5, AWARD-6 and AWARD-1. AWARD-5 and AWARD-1 patients randomised to receive placebo were not included in the analysis. The design and results of these trials have been previously published [13-15]. Each of these original studies was conducted in accordance with the Declaration of Helsinki guidelines on good clinical practice. In all cases the protocol was approved by local institutional review boards, and all patients provided written informed consent before participation in the trial [13-15]. The full list of institutional review boards that approved the three studies can be found in the Supplementary Material (Table S1). A summary of each of these trials is provided below. 
In AWARD-5 [13], 921 patients with T2DM on metformin ( $\geq 1500 \mathrm{mg} /$ day) were randomised to receive concomitant therapy with once-weekly dulaglutide $1.5 \mathrm{mg}$ or $0.75 \mathrm{mg}$, or once-daily sitagliptin $100 \mathrm{mg}$. Patients were eligible for inclusion if, at screening, their $\mathrm{HbA}_{1 \mathrm{c}}$ was $>8 \%$ and $\leq 9.5 \% \quad(>63.9$ and $80.3 \mathrm{mmol} / \mathrm{mol}$ ), if treated with diet and exercise, or $\geq 7.0 \%$ and $\leq 9.5 \% \quad(\geq 53.0$ and $\leq 80.3 \mathrm{mmol} / \mathrm{mol}$ ) if receiving oral antihyperglycaemic medication. Eligible patients then entered a lead-in period that lasted up to 11 weeks. During the lead-in period, patients received metformin monotherapy (minimum dose $\geq 1500 \mathrm{mg} /$ day) for $\geq 6$ weeks prior to randomisation; all other oral antihyperglycaemic medications were discontinued.

In AWARD-6 [14], 599 patients with T2DM on metformin ( $\geq 1500 \mathrm{mg} /$ day) were randomised to receive concomitant therapy with once-weekly dulaglutide $1.5 \mathrm{mg}$ or once-daily liraglutide $1.8 \mathrm{mg}$. Patients treated with antihyperglycaemic drugs other than metformin were excluded. The inclusion criteria included an $\mathrm{HbA}_{1 \mathrm{c}}$ level $\geq 7.0 \%$ and $\leq 10.0 \%(\geq 53.0$ and $\leq 85.8 \mathrm{mmol} / \mathrm{mol}$ ) at screening. This study did not include a lead-in period.

In AWARD-1 [15], 835 patients with T2DM on maximally tolerated doses of metformin (1500-3000 mg/day) and pioglitazone (30$45 \mathrm{mg} /$ day) were randomised to receive concomitant therapy with once-weekly dulaglutide $1.5 \mathrm{mg}$ or $0.75 \mathrm{mg}$, or exenatide $10 \mu \mathrm{g}$ twice daily. At screening, patients were eligible for inclusion if their $\mathrm{HbA}_{1 \mathrm{c}}$ was $\geq 7.0 \%$ and $\leq 11.0 \%$ ( $\geq 53.0$ and $\leq 96.7 \mathrm{mmol} / \mathrm{mol})$, if on oral antihyperglycaemic medication monotherapy, or $\geq 7.0 \%$ and $\leq 10.0 \% \quad(\geq 53.0$ and $\leq 85.8 \mathrm{mmol} / \mathrm{mol}$ ) if on combination oral antihyperglycaemic medication. After a lead-in period that lasted up to 12 weeks, patients were eligible for randomisation if their $\mathrm{HbA}_{1 \mathrm{c}}$ was $>6.5 \%$ ( $>47.5 \mathrm{mmol} / \mathrm{mol}$ ). Previous oral antihyperglycaemic medications other than metformin and pioglitazone were discontinued during the lead-in period.

In the current post hoc analysis, changes in $\mathrm{HbA}_{1 \mathrm{c}}$ were evaluated at week 26 for each of the trials (AWARD-5, AWARD-6 and AWARD-1). Week-52 data are available for one study only
(AWARD-5) and are mentioned briefly. Data were analysed by study using last observation carried forward (LOCF) analysis of covariance (ANCOVA), starting with the predefined statistical models from the respective study protocols, which assumed a linear association between baseline $\mathrm{HbA}_{1 \mathrm{c}}$ and change in $\mathrm{HbA}_{1 \mathrm{c}}$.

Backward selection methods were applied to assess whether the respective predefined models were appropriately capturing this linear association or needed to be adapted. In order to produce meaningful and interpretable estimates and $P$ values for the factor treatment, the factor for baseline $\mathrm{HbA}_{1 \mathrm{c}}$ and the treatment-by-baseline $\mathrm{HbA}_{1 \mathrm{c}}$ factor were centred around a baseline $\mathrm{HbA}_{1 \mathrm{c}}$ of $8.0 \% \quad(63.9 \mathrm{mmol} / \mathrm{mol})$. Consistency of potential treatment effect across the range of baseline $\mathrm{HbA}_{1 \mathrm{c}}$ values was investigated via the corresponding treatment-by-baseline $\mathrm{HbA}_{1 \mathrm{c}}$ interaction term, with $P<0.1$ interpreted as a potential differential treatment effect. Sensitivity analyses were performed as appropriate, using only data from patients treated with active therapy in the ITT population of each study who met the $\mathrm{HbA}_{1 \mathrm{c}}$ inclusion criteria.

Baseline characteristics data are presented for the active treatment arms (dulaglutide and incretin-based comparators) of the ITT population of each study; full baseline characteristics for each of the respective studies have been previously published [13-15].

\section{RESULTS}

\section{Patient Characteristics}

Baseline characteristics for the patients in the ITT population who were enrolled in the three phase III studies and received active treatment are shown in Table 1. Patients in AWARD-6 and AWARD-1 tended to have a higher weight and body mass index than those in AWARD-5, and the disease duration was longer in AWARD-1 than in AWARD-5 and AWARD-6. All other baseline characteristics were similar across the studies [13-15]. The mean baseline $\mathrm{HbA}_{1 \mathrm{c}}$ was generally similar (mean value, $8.1 \%$ $[65.0 \mathrm{mmol} / \mathrm{mol}]$ in all treatment groups across 


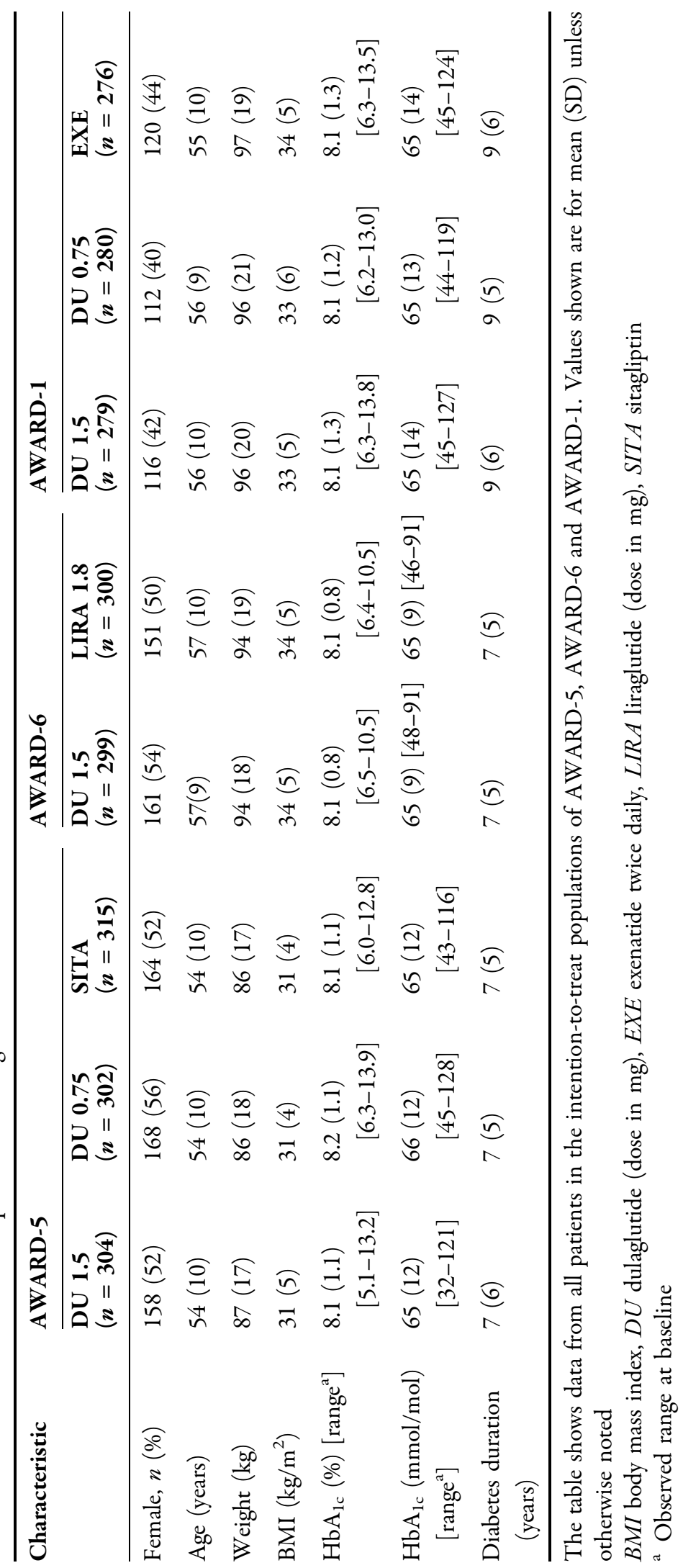


the studies), although the range of baseline $\mathrm{HbA}_{1 \mathrm{c}}$ values (Tables 1, 2 and S2; Fig. 1) differed among studies as a result of differences in study inclusion/exclusion criteria (see "Methods" section).

\section{$\mathrm{HbA}_{1 \mathrm{c}}$ Changes}

Improvements in $\mathrm{HbA}_{1 \mathrm{c}}$ at 26 weeks occurred in all treatment groups across the entire baseline $\mathrm{HbA}_{1 \mathrm{c}}$ range in all studies (Fig. 1; Tables 2 and S1).

Table S3 shows details of the backward selection process and the variables excluded from each ANCOVA model. The association between baseline $\mathrm{HbA}_{1 \mathrm{c}}$ and change in $\mathrm{HbA}_{1 \mathrm{c}}$ was best described by a linear relationship in all studies, with greater reductions in $\mathrm{HbA}_{1 \mathrm{c}}$ occurring in patients with higher $\mathrm{HbA}_{1 \mathrm{c}}$ levels at baseline (Table S3; Fig. 1). Therefore, the predefined models did not need to be adapted. At week 26 , dulaglutide $1.5 \mathrm{mg}$ was associated with mean reductions of $<1 \% \quad(<10.9 \mathrm{mmol} / \mathrm{mol})$ in patients with good control (baseline $\mathrm{HbA}_{1 \mathrm{c}}$ levels of $\leq 7 \% \quad[53.0 \mathrm{mmol} / \mathrm{mol}])$ in each of the AWARD-5, AWARD-6 and AWARD-1 studies, and with greater mean reductions (1.8-3.2\% [19.7-35.0 $\mathrm{mmol} / \mathrm{mol}])$ in those with poorer control $\left(\mathrm{HbA}_{1 \mathrm{c}} \geq 9.5 \%[80.3 \mathrm{mmol} / \mathrm{mol}]\right)$. This pattern was also apparent in patients treated with dulaglutide $0.75 \mathrm{mg}$ (AWARD-5 and AWARD-1), although the magnitude of the reduction in $\mathrm{HbA}_{1 \mathrm{c}}$ was slightly smaller at the lower dose (Fig. 1a, c).

The overall magnitude of the mean reduction in $\mathrm{HbA}_{1 \mathrm{c}}$ at 26 weeks across the continuum of baseline $\mathrm{HbA}_{1 \mathrm{c}}$ values was greater in patients receiving dulaglutide $1.5 \mathrm{mg}$ than in those receiving sitagliptin (AWARD-5; Fig. 1a) or exenatide twice daily (AWARD-1; Fig. 1c) and was similar to patients receiving liraglutide $1.8 \mathrm{mg}$ (AWARD-6; Fig. 1b). These findings are in line with the results of the primary analyses [13-15].

Treatment-by-baseline $\mathrm{HbA}_{1 \mathrm{c}}$ interaction terms for AWARD-6 (interaction $P$ value $=$ 0.605; Fig. 1b) and AWARD-1 (interaction $P$ value $=0.443$; Fig. $1 \mathrm{c})$ indicated no differences in the relative change in $\mathrm{HbA}_{1 \mathrm{c}}$ in patients treated with dulaglutide versus those treated with sitagliptin or exenatide twice daily across the whole range of baseline $\mathrm{HbA}_{1 \mathrm{c}}$. This is also illustrated by the similar slopes of the lines describing the relationship between $\mathrm{HbA}_{1 \mathrm{c}}$ baseline and change from baseline. For AWARD-1, a sensitivity analysis on the ITT population using $\mathrm{HbA}_{1 \mathrm{c}}$ values within the inclusion criteria only (7.0-11.0\% [53-97 mmol/mol]) confirmed this outcome.

In contrast, in AWARD-5, the treatment-bybaseline $\mathrm{HbA}_{1 \mathrm{c}}$ interaction $P$ value was significant $(P=0.001$; Fig. $1 \mathrm{a})$. This was mainly driven by the progressively greater $\mathrm{HbA}_{1 \mathrm{c}}$ reduction that occurred in patients treated with dulaglutide $1.5 \mathrm{mg}$ compared with sitagliptin as baseline $\mathrm{HbA}_{1 \mathrm{c}}$ increased (estimated treatment group differences in $\mathrm{HbA}_{1 \mathrm{c}}$ reduction [dulaglutide minus comparator $]$ of $-0.35 \%[-3.83 \mathrm{mmol} / \mathrm{mol}]$ and $-0.95 \%$ [ $-10.38 \mathrm{mmol} / \mathrm{mol}]$ at baseline $\mathrm{HbA}_{1 \mathrm{c}}$ values of $7.0 \%$ [53.0 mmol/mol] and $9.5 \%$ [80.3 mmol/mol], respectively; pairwise interaction $P$ value $=0.0003$ ). The estimated difference between the change in $\mathrm{HbA}_{1 \mathrm{c}}$ in the dulaglutide $0.75 \mathrm{mg}$ and sitagliptin treatment groups also increased as baseline $\mathrm{HbA}_{1 \mathrm{c}}$ increased, but to a lesser extent (baseline $\mathrm{HbA}_{1 \mathrm{c}}=7.0 \%[53.0 \mathrm{mmol} /$ $\mathrm{mol}],-0.31 \%$ [- $3.39 \mathrm{mmol} / \mathrm{mol}] ; 9.5 \%$ [80.3 $\mathrm{mmol} / \mathrm{mol}],-0.52 \%$ [- $5.68 \mathrm{mmol} / \mathrm{mol}]$; pairwise interaction $P$ value $=0.1778$ ). These results were also observed in the 52-week analysis (primary endpoint; interaction $P$ value $<0.001$ ) [27]. At this time point, the estimated treatment group differences for dulaglutide compared to sitagliptin were greater than at 26 weeks, and the pairwise interaction $P$ values were significant for both dulaglutide $1.5 \mathrm{mg}\left(P<0.001\right.$; baseline $\mathrm{HbA}_{1 \mathrm{c}}=$ $7.0 \% \quad[53.0 \mathrm{mmol} / \mathrm{mol}]$, estimated treatment group difference $=-0.36 \% \quad[-3.94 \mathrm{mmol} /$ $\mathrm{mol}$ ], $9.5 \%$ [ $80.3 \mathrm{mmol} / \mathrm{mol}],-1.15 \%$ [- 12.57 $\mathrm{mmol} / \mathrm{mol}])$ and $0.75 \mathrm{mg}(P=0.026$; baseline $\mathrm{HbA}_{1 \mathrm{c}}=7.0 \%[53.0 \mathrm{mmol} / \mathrm{mol}],-0.29 \%[-3.17$ $\mathrm{mmol} / \mathrm{mol}], \quad 9.5 \% \quad[80.3 \mathrm{mmol} / \mathrm{mol}],-0.69 \%$ $[-7.54 \mathrm{mmol} / \mathrm{mol}])$.

\section{DISCUSSION}

By investigating $\mathrm{HbA}_{1 \mathrm{c}}$ reduction across the continuum of baseline $\mathrm{HbA}_{1 \mathrm{c}}$ values, this exploratory post hoc analysis of data from the 


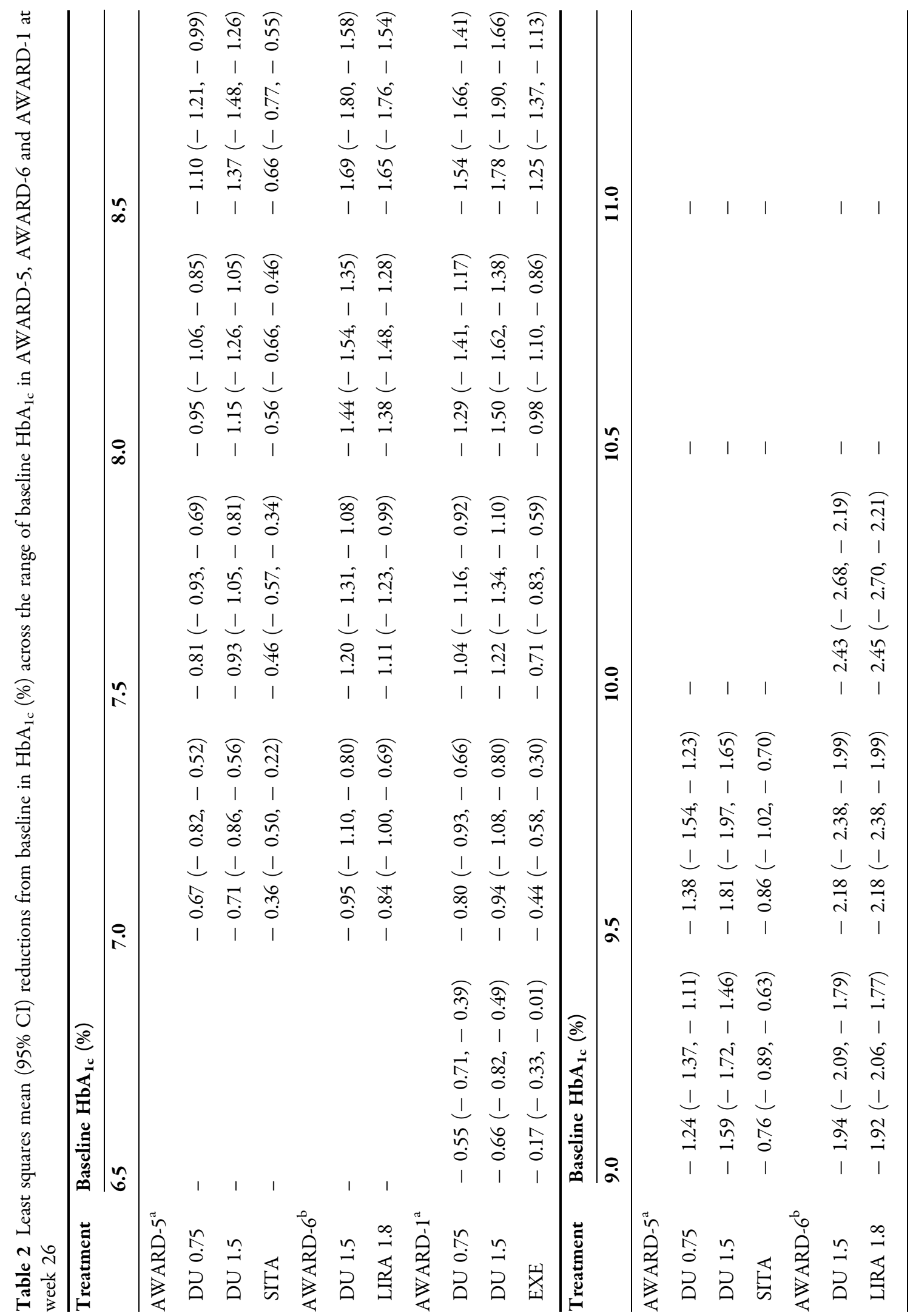




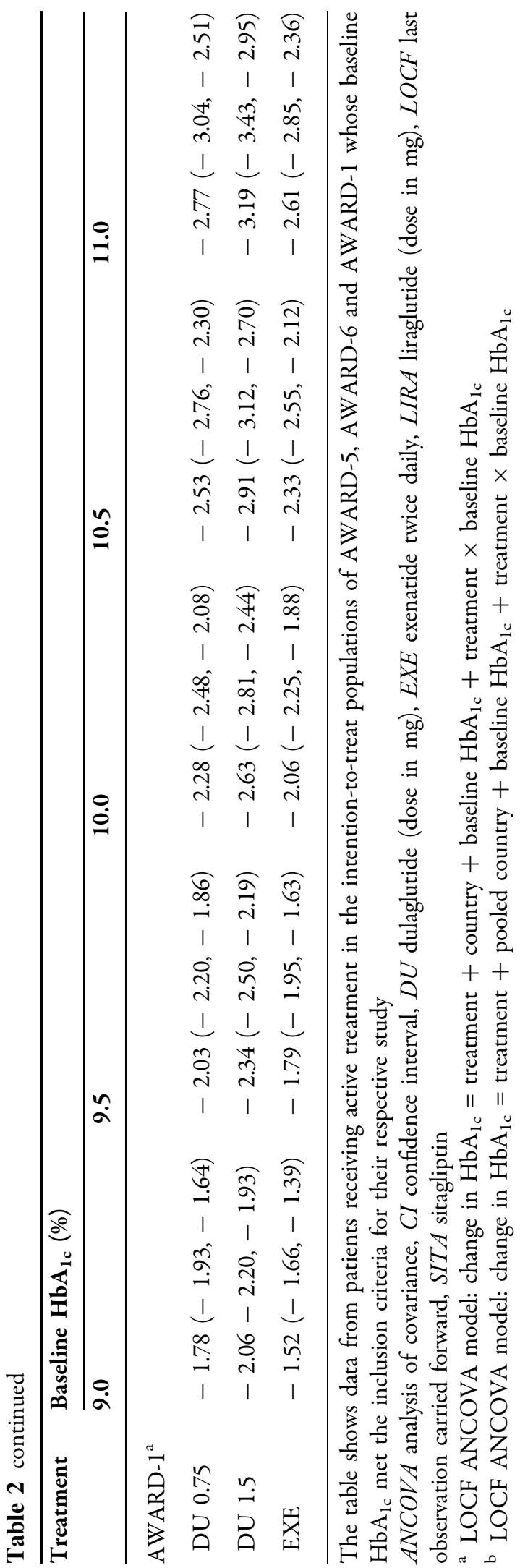

Fig. 1 Change in $\mathrm{HbA}_{1 \mathrm{c}}$ by baseline $\mathrm{HbA}_{1 \mathrm{c}}$ and treatment group estimated using LOCF ANCOVA models (for each study, data are presented only for baseline $\mathrm{HbA}_{1 \mathrm{c}}$ values that correspond to the study inclusion criteria). a AWARD-5, 26 weeks. LOCF ANCOVA model: treatment + country + baseline $\mathrm{HbA}_{1 \mathrm{c}}+$ treatment $\times$ baseline $\mathrm{HbA}_{1 \mathrm{c}}$, interaction $P$ value $=0.001$. b AWARD-6, 26 weeks (primary endpoint). LOCF ANCOVA model: treatment + pooled country + baseline $\mathrm{HbA}_{1 \mathrm{c}}+$ treatment $\times$ baseline $\mathrm{HbA}_{1 \mathrm{c}}$; interaction $P$ value $=0.605$. c AWARD-1, 26 weeks (primary endpoint). LOCF ANCOVA model: treatment + country + baseline $\mathrm{HbA}_{1 \mathrm{c}}+$ treatment $\times$ baseline $\mathrm{HbA}_{1 \mathrm{c}} ;$ interaction $P$ value $=0.443$. ANCOVA analysis of covariance, BID twice daily, CI confidence interval, DU dulaglutide, EXE exenatide, LIRA liraglutide, LOCF last observation carried forward, SITA sitagliptin

AWARD-5, AWARD-6 and AWARD-1 studies provides an in-depth evaluation of the primary results of these studies. The results of the current analysis indicate that incretin-based therapies effectively lowered $\mathrm{HbA}_{1 \mathrm{c}}$ irrespective of the $\mathrm{HbA}_{1 \mathrm{c}}$ value at baseline. Across the range of baseline $\mathrm{HbA}_{1 \mathrm{c}}$, patients treated with dulaglutide $1.5 \mathrm{mg}$ achieved a similar mean reduction in $\mathrm{HbA}_{1 \mathrm{c}}$ to patients treated with liraglutide $1.8 \mathrm{mg}$ (AWARD-6: Fig. 1b), and a greater $\mathrm{HbA}_{1 \mathrm{c}}$ mean reduction than patients treated with exenatide twice daily (AWARD-1; Fig. 1c) or sitagliptin (AWARD-5; Fig. 1a). These results are consistent with the primary analyses, which assumed the same effect of baseline $\mathrm{HbA}_{1 \mathrm{c}}$ for the whole ITT population [13-15].

The current analysis complements previous post hoc analyses [24, 25], which have categorised patients into distinct subgroups based on baseline $\mathrm{HbA}_{1 \mathrm{c}}$ cutoff values (e.g. $<8.5 \%$ vs $\geq 8.5 \%$ [69.4 $\mathrm{mmol} / \mathrm{mol}])$. It has shown that in dulaglutide $1.5 \mathrm{mg}$ and $0.75 \mathrm{mg}$ treatment groups, $\mathrm{HbA}_{1 \mathrm{c}}$ was reduced in patients with baseline $\mathrm{HbA}_{1 \mathrm{c}}$ levels that ranged from $6.5 \%$ $(47.5 \mathrm{mmol} / \mathrm{mol})$ to $11.0 \% \quad(96.7 \mathrm{mmol} / \mathrm{mol})$ (Fig. 1). Once-daily sitagliptin and liraglutide $1.8 \mathrm{mg}$, and twice-daily exenatide, were also associated with reduced $\mathrm{HbA}_{1 \mathrm{c}}$ in patients with a range of baseline $\mathrm{HbA}_{1 \mathrm{c}}$ levels (sitagliptin, $\mathrm{HbA}_{1 \mathrm{c}} 7.0-9.5 \%$ [53.0-80.3 mmol/mol]; liraglutide $1.8 \mathrm{mg}, \quad \mathrm{HbA}_{1 \mathrm{c}} \quad 7.0-10.0 \%$ [53.0- 

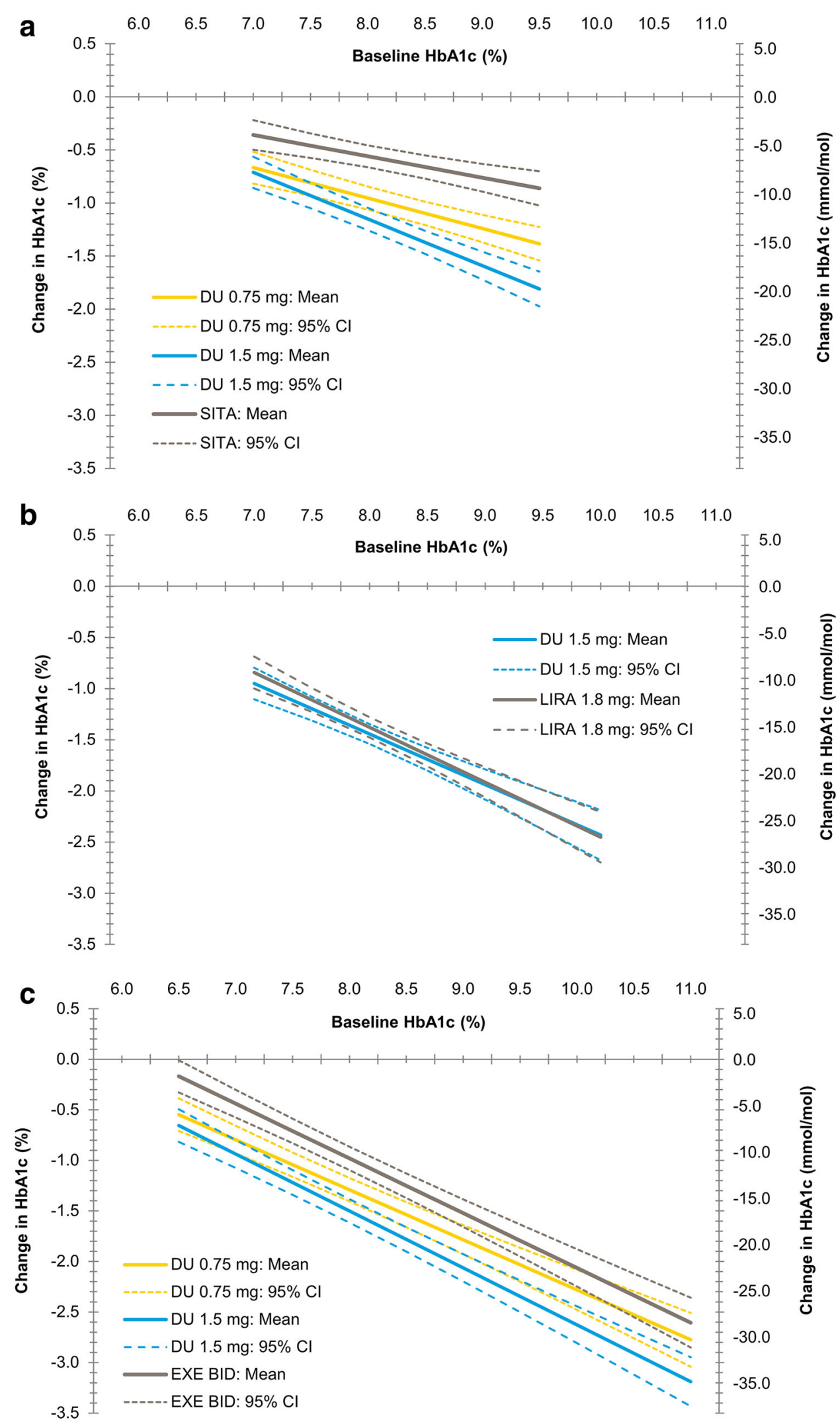
$85.8 \mathrm{mmol} / \mathrm{mol}$; exenatide, $\mathrm{HbA}_{1 \mathrm{c}} 6.5-11.0 \%$ [47.5-96.7 mmol/mol]; Fig. 1). These findings suggest that improvements in glycaemic control can be achieved with incretin-based therapies irrespective of the patient's $\mathrm{HbA}_{1 \mathrm{c}}$ value at the time therapy is initiated. Such improvements in glycaemic control will help to decrease the risk of microvascular complications across the broad spectrum of patients with T2DM $[28,29]$.

Moreover, in this post hoc analysis, there was a positive linear relationship between $\mathrm{HbA}_{1 \mathrm{c}}$ reduction at 26 weeks and baseline $\mathrm{HbA}_{1 \mathrm{c}}$ in patients treated with dulaglutide or liraglutide in AWARD-6, in patients treated with dulaglutide or exenatide twice-daily in AWARD-1, and in patients treated with dulaglutide or sitagliptin in AWARD-5 (Fig. 1). In dulaglutide $1.5 \mathrm{mg}$ treated patients with better glycaemic control at baseline $\left(\mathrm{HbA}_{1 \mathrm{c}}=7 \% \quad[53.0 \mathrm{mmol} / \mathrm{mol}]\right)$, the reductions were $<1 \%(10.9 \mathrm{mmol} / \mathrm{mol})$ in each of the AWARD-5, AWARD-6 and AWARD-1 studies at 26 weeks. In contrast, mean reductions ranged from $1.8 \%$ to $3.2 \%$ $(19.8-35.0 \mathrm{mmol} / \mathrm{mol}])$ at 26 weeks in patients with poorer control at baseline $\left(\mathrm{HbA}_{1 \mathrm{c}} \geq 9.5 \%\right.$ [ $80.3 \mathrm{mmol} / \mathrm{mol}]$ ) who received dulaglutide $1.5 \mathrm{mg}$. These outcomes are consistent with another post hoc analysis, which found that a higher baseline $\mathrm{HbA}_{1 \mathrm{c}}$ value reflecting poor glycaemic status was a major factor associated with a greater reduction in $\mathrm{HbA}_{1 \mathrm{c}}$ [11]. A positive relationship between baseline $\mathrm{HbA}_{1 \mathrm{c}}$ and the magnitude of $\mathrm{HbA}_{1 \mathrm{c}}$ reduction has been reported in meta-analyses involving insulin analogues [6] and ten categories of glucose-lowering therapies [30], and in the nomogram developed by Esposito et al. [8] to estimate the $\mathrm{HbA}_{1 \mathrm{c}}$ to estimate the $\mathrm{HbA}_{1 \mathrm{c}}$ response to different DPP-4 inhibitors.

The positive linear relationship that exists between incretin-associated $\mathrm{HbA}_{1 \mathrm{c}}$ reduction and baseline $\mathrm{HbA}_{1 \mathrm{c}}$ was evident with dulaglutide and liraglutide treatments in AWARD-6, with dulaglutide and exenatide twice-daily treatments in AWARD-1 and with dulaglutide and sitagliptin treatments in AWARD-5. There was no evidence of a significant treatment-bybaseline $\mathrm{HbA}_{1 \mathrm{c}}$ interaction in AWARD-6 or AWARD-1 (interaction $P$ values, 0.605 and 0.443 , respectively); however, a significant interaction was demonstrated in patients treated with dulaglutide versus sitagliptin in AWARD-5 $(P$ value $=0.001)$, with a progressively greater $\mathrm{HbA}_{1 \mathrm{c}}$ reduction associated with dulaglutide $1.5 \mathrm{mg}$ compared with sitagliptin as baseline $\mathrm{HbA}_{1 \mathrm{c}}$ increased. This significant interaction was confirmed at 52 weeks [27]. The greater $\mathrm{HbA}_{1 \mathrm{c}}$ reduction in patients with higher baseline $\mathrm{HbA}_{1 \mathrm{c}}$ seen in those treated with dulaglutide $1.5 \mathrm{mg}$, compared with sitagliptin, could be related to the greater effect that GLP-1 RAs have on both fasting and postprandial glucose levels [13, 30].

This post hoc analysis indicates that consideration of a patient's baseline $\mathrm{HbA}_{1 \mathrm{c}}$ level is important because the glycaemic response varies among patients treated with different antihyperglycaemic agents, and these variances may be magnified at higher baseline $\mathrm{HbA}_{1 \mathrm{c}}$ levels (Fig. 1). In light of the relationship between the patient's baseline $\mathrm{HbA}_{1 \mathrm{c}}$ and their changes in $\mathrm{HbA}_{1 \mathrm{c}}$, this analysis highlights an opportunity for personalising therapy. Such personalisation of therapy is increasingly being seen as important in the optimal clinical management of patients with T2DM [31], with the patient's age, their attitude to specific adverse effects of therapy, the presence of comorbid conditions and the duration of T2DM all being considered when a therapeutic strategy is being considered [32].

This analysis has a number of limitations. These include the open-label design of AWARD6 and AWARD-1 (which could have affected physicians' and patients' behaviour), the exploratory post hoc nature of the analysis and the absence of placebo-based correction for the absolute reductions in $\mathrm{HbA}_{1 \mathrm{c}}$ (only two of the three original AWARD trials included a placebo arm [13-15] and the data must be interpreted in the context of the absence of placebo data). In terms of the ANCOVA models used in the analysis, these did not include factors potentially associated with $\mathrm{HbA}_{1 \mathrm{c}}$ such as age and duration of diabetes $[33,34]$. Although this may be regarded as a limitation, use of the simpler models allowed us to remain consistent with the original, pre-planned statistical analysis. Moreover, baseline $\mathrm{HbA}_{1 \mathrm{c}}$ is the major factor associated with change in $\mathrm{HbA}_{1 \mathrm{c}}$, irrespective of 
treatment [10]. A post hoc analysis of studies involving dulaglutide showed that baseline $\mathrm{HbA}_{1 \mathrm{c}}$ accounted for $49 \%$ of relative influence, whereas the relative influence of other baseline characteristics such as age, fasting serum glucose or duration of diabetes was very small or of limited clinical significance [11]. Consistency with the original analysis was also maintained by focussing solely on $\mathrm{HbA}_{1 \mathrm{c}}$ change from baseline; this outcome was the primary endpoint in the AWARD trials and therefore the most suitable for exploration in this analysis. It should be noted that, because this analysis presents data only for the baseline $\mathrm{HbA}_{1 \mathrm{c}}$ ranges specified by the inclusion criteria in each study, no conclusions can be drawn regarding the effect of incretin-based therapy in patients with $\mathrm{HbA}_{1 \mathrm{c}}$ levels outside these ranges.

\section{CONCLUSION}

The current post hoc analysis complements the primary analyses of the AWARD studies. Results indicate that patients treated with dulaglutide 1.5 and $0.75 \mathrm{mg}$ experienced mean reductions in $\mathrm{HbA}_{1 \mathrm{c}}$ that were greater than those of patients treated with either exenatide twice daily or sitagliptin, and in patients treated with dulaglutide $1.5 \mathrm{mg}, \mathrm{HbA}_{1 \mathrm{c}}$ was reduced to the same extent as that seen in patients treated with liraglutide $1.8 \mathrm{mg}$, in all cases irrespective of the patient's baseline $\mathrm{HbA}_{1 \mathrm{c}}$ value. Since dulaglutide's ability to lower $\mathrm{HbA}_{1 \mathrm{c}}$ is durable and has been observed across patients with a broad range of $\mathrm{HbA}_{1 \mathrm{c}}$ levels, these results suggest that dulaglutide may be considered an appropriate option for a wide range of baseline $\mathrm{HbA}_{1 \mathrm{c}}$ levels, including those indicative of poor glycaemic control.

\section{ACKNOWLEDGEMENTS}

Funding. Sponsorship for this study and the article processing charges were funded by Eli Lilly and Company. All authors had full access to all of the data in this study and take complete responsibility for the integrity of the data and the accuracy of the data analysis.

Medical Writing Assistance. The authors would like to acknowledge Janet Douglas (Rx Communications, Mold, UK) for medical writing assistance with the preparation of this article, funded by Eli Lilly and Company.

Authorship. All named authors meet the International Committee of Medical Journal Editors (ICMJE) criteria for authorship for this article, take responsibility for the integrity of the work as a whole, and have given their approval for this version to be published.

Authorship Contributions. RG and LAV were involved with the conception of the work and interpretation of the data. IR, RB and GS were involved with the interpretation of the data for the work. $\mathrm{CN}$ was involved with the conception and design of the work, and the analysis and interpretation of the data.

Disclosures. Irene Romera is a full-time employee and shareholder of Eli Lilly and Company. Claudia Nicolay is a full-time employee and shareholder of Eli Lilly and Company. Luis Alberto Vázquez was an employee of Eli Lilly and Company during the inception of this study. Raffaella Gentilella was an employee of Eli Lilly and Company during the inception of this study, and now serves as a consultant for Eli Lilly Italy. Raffaella Buzzetti has attended an advisory panel for Eli Lilly and Company, and for Sanofi; has been a board member for Abbott and Takeda; has attended a speakers' bureau for AstraZeneca, Eli Lilly and Company, Medtronic, Novo Nordisk, Sanofi and Takeda. Giorgio Sesti has nothing to disclose.

Compliance with Ethics Guidelines. This article is based on the results of three previously conducted studies, all of which involved human participants. Each of these original studies was conducted in accordance with the Declaration of Helsinki guidelines on good clinical practice. In all cases the protocol was approved by local institutional review boards and all patients 
provided written informed consent before participation in the trial. The full list of institutional review boards that approved the three studies can be found in the Supplementary Material (Table S1).

Data Availability. All data generated or analysed during this study are included in this published article/as supplementary information files.

Open Access. This article is distributed under the terms of the Creative Commons Attribution-NonCommercial 4.0 International License (http://creativecommons.org/licenses/ by-nc/4.0/), which permits any noncommercial use, distribution, and reproduction in any medium, provided you give appropriate credit to the original author(s) and the source, provide a link to the Creative Commons license, and indicate if changes were made.

\section{REFERENCES}

1. Htike ZZ, Zaccardi F, Papamargaritis D, Webb DR, Khunti K, Davies MJ. Efficacy and safety of glucagon-like peptide- 1 receptor agonists in type 2 diabetes: a systematic review and mixed-treatment comparison analysis. Diabetes Obes Metab. 2017;19(4):524-36.

2. Nauck M. Incretin therapies: highlighting common features and differences in the modes of action of glucagon-like peptide-1 receptor agonists and dipeptidyl peptidase- 4 inhibitors. Diabetes Obes Metab. 2016;18(3):203-16.

3. Drab SR. Glucagon-like peptide-1 receptor agonists for type 2 diabetes: a clinical update of safety and efficacy. Curr Diabetes Rev. 2016;12(4): 403-13.

4. Gentilella R, Pechtner V, Corcos A, Consoli A. Glucagon-like peptide-1 receptor agonists in type 2 diabetes treatment: are they all the same? Diabetes Metab Res Rev. 2018;35:e3070. https://doi.org/10. 1002/dmrr.3070.

5. DeFronzo RA, Stonehouse AH, Han J, Wintle ME. Relationship of baseline HbA1c and efficacy of current glucose-lowering therapies: a meta-analysis of randomized clinical trials. Diabet Med. 2010;27:309-17.
6. Giugliano D, Maiorino M, Bellastella G, Chiodini P, Esposito K. Relationship of baseline HbA1c, HbA1c change and HbA1c target of $<7 \%$ with insulin analogues in type 2 diabetes: a meta-analysis of randomised controlled trials. Int $\mathrm{J}$ Clin Pract. 2011;65:602-12.

7. Grimm M, Han J, Weaver C, et al. Efficacy, safety, and tolerability of exenatide once weekly in patients with type 2 diabetes mellitus: an integrated analysis of the DURATION trials. Postgrad Med. 2013;125:47-57.

8. Esposito $\mathrm{K}$, Chiodini $\mathrm{P}$, Maiorino $\mathrm{MI}$, et al. A nomogram to estimate the HbA1c response to different DPP- 4 inhibitors in type 2 diabetes: a systematic review and meta-analysis of 98 trials with 24163 patients. BMJ Open. 2015;5:e005892.

9. Lapolla A, Frison V, Bettio M, et al. Correlation between baseline characteristics and clinical outcomes in a large population of diabetes patients treated with liraglutide in a real-world setting in Italy. Clin Ther. 2015;37:574-84.

10. Cantrell RA, Alatorre CI, Davis EJ, et al. A review of treatment response in type 2 diabetes: assessing the role of patient heterogeneity. Diabetes Obes Metab. 2010;12:845-57.

11. Wysham C, Guerci B, D'Alessio D, Jia N, Botros FT. Baseline factors associated with glycaemic response to treatment with once-weekly dulaglutide in patients with type 2 diabetes. Diabetes Obes Metab. 2016;18(11):1138-42.

12. Umpierrez G, Tofé Povedano S, Pérez Manghi F, Shurzinske L, Pechtner V. Efficacy and safety of dulaglutide monotherapy versus metformin in type 2 diabetes in a randomized controlled trial (AWARD-3). Diabetes Care. 2014;37:2168-76.

13. Nauck M, Weinstock RS, Umpierrez GE, Guerci B, Skrivanek Z, Milicevic Z. Efficacy and safety of dulaglutide versus sitagliptin after 52 weeks in type 2 diabetes in a randomized controlled trial (AWARD-5). Diabetes Care. 2014;37:2149-58.

14. Dungan KM, Povedano ST, Forst T, et al. Onceweekly dulaglutide versus once-daily liraglutide in metformin-treated patients with type 2 diabetes (AWARD-6): a randomised, open-label, phase 3, non-inferiority trial. Lancet. 2014;384:1349-57.

15. Wysham C, Blevins T, Arakaki R, et al. Efficacy and safety of dulaglutide added onto pioglitazone and metformin versus exenatide in type 2 diabetes in a randomized controlled trial (AWARD-1). Diabetes Care. 2014;37:2159-67.

16. Giorgino F, Benroubi M, Sun JH, Zimmermann AG, Pechtner V. Efficacy and safety of once-weekly 
dulaglutide versus insulin glargine in patients with type 2 diabetes on metformin and glimepiride (AWARD-2). Diabetes Care. 2015;38:2241-9.

17. Blonde L, Jendle J, Gross J, Woo V, Jiang H, Fahrbach JL, et al. Once-weekly dulaglutide versus bedtime insulin glargine, both in combination with prandial insulin lispro, in patients with type 2 diabetes (AWARD-4): a randomised, open-label, phase 3, non-inferiority study. Lancet. 2015;385:2057-66.

18. Dungan KM, Weitgasser R, Perez Manghi F, et al. A 24-week study to evaluate the efficacy and safety of once-weekly dulaglutide added on to glimepiride in type 2 diabetes (AWARD-8). Diabetes Obes Metab. 2016;18:475-82.

19. Zhang L, Zhang M, Zhang Y, Tong N. Efficacy and safety of dulaglutide in patients with type 2 diabetes: a meta-analysis and systematic review. Sci Rep. 2016;6:18904.

20. Weinstock RS, Guerci B, Umpierrez G, Nauck MA, Skrivanek Z, Milicevic Z. Safety and efficacy of onceweekly dulaglutide versus sitagliptin after 2 years in metformin-treated patients with type 2 diabetes (AWARD-5): a randomized, phase III study. Diabetes Obes Metab. 2015;17:849-58.

21. Jendle J, Grunberger G, Blevins T, Giorgino F, Hietpas RT, Botros FT. Efficacy and safety of dulaglutide in the treatment of type 2 diabetes: a comprehensive review of the dulaglutide clinical data focusing on the AWARD phase 3 clinical trial program. Diabetes Metab Res Rev. 2016;32(8): 776-90.

22. Johnson JF, Parsa R, Bailey RA. Real-world clinical outcomes among patients with type 2 diabetes receiving canagliflozin at a specialty diabetes clinic: subgroup analysis by baseline HbA1c and age. Clin Ther. 2017;39:1123-31.

23. Tsoukas G, Bain S, Araki E, et al. Semaglutide reduces $\mathrm{HbA1c}$ across baseline $\mathrm{HbA1c}$ subgroups across SUSTAIN 1-5 clinical trials. Can J Diabetes. 2017;41(5):S50.

24. Bain SC, Skrivanek Z, Tahbaz A, Pechtner V, Adetunji O. Efficacy of long acting once weekly dulaglutide compared with short acting twice daily (bid) exenatide in patients with type 2 diabetes mellitus (T2DM). A post-hoc analysis to determine the influence of baseline HbA1c in the AWARD-1 trial. Presented at diabetes UK professional conference: 2014 March 5-7; ACC Liverpool. 2014. p. 79.
25. Gallwitz B, Dagogo-Jack S, Thieu V, et al. Effect of once-weekly dulaglutide on glycated haemoglobin (HbA1c) and fasting blood glucose in patient subpopulations by gender, duration of diabetes and baseline HbA1c. Diabetes Obes Metab. 2017;20: 409-18.

26. Altman DG, Royston P. The costs of dichotomising continuous variables. BMJ. 2006;332:1080.

27. Gentilella R, Sesti G, Buzzetti R, Vázquez LA, Nicolay C. Consistency of treatment effect across the range of baseline $\mathrm{HbA} 1 \mathrm{c}$ in patients with type 2 diabetes mellitus (T2DM) treated with once-weekly dulaglutide or comparators in AWARD-1, -5 and -6. Presented at diabetes UK professional conference: 2016 March 2-4; Glasgow, UK. 2016. p. 526.

28. Holman RR, Paul SK, Bethel MA, Matthews DR, Neil HA. 10-year follow-up of intensive glucose control in type 2 diabetes. N Engl J Med. 2008;359:1577-89.

29. Hemmingsen B, Lund SS, Gluud C, et al. Targeting intensive glycaemic control versus targeting conventional glycaemic control for type 2 diabetes mellitus. Cochrane Database Syst Rev. 2013;(11): CD008143.

30. DeFronzo RA, Okerson T, Viswanathan P, Guan X, Holcombe JH, MacConell L. Effects of exenatide versus sitagliptin on postprandial glucose, insulin and glucagon secretion, gastric emptying, and caloric intake: a randomized, cross-over study. Curr Med Res Opin. 2008;24:2943-52.

31. Gallo M, Mannucci E, De Cosmo S, et al. Algorithms for personalized therapy of type 2 diabetes: results of a web-based international survey. BMJ Open Diabetes Res Care. 2015;3:e000109.

32. Paschou SA, Leslie RD. Personalizing guidelines for diabetes management: twilight or dawn of the expert? BMC Med. 2013;11:161.

33. Dubowitz N, Xue W, Long Q, et al. Aging is associated with increased HbA1c levels, independently of glucose levels and insulin resistance, and also with decreased HbA1c diagnostic specificity. Diabet Med. 2014;31:927-35.

34. Verma M, Paneri S, Badi P, Raman PG. Effect of increasing duration of diabetes mellitus type 2 on glycated hemoglobin and insulin sensitivity. Indian J Clin Biochem. 2006;21:142-6. 